\title{
Unusual Fishing Behavior of the Eurasian Sparrowhawk (Accipiter nisus)
}

\author{
Author(s): Béla Mester Thomas Oliver Mérő
}

Source: Journal of Raptor Research, 52(1):112-114.

Published By: The Raptor Research Foundation

https://doi.org/10.3356/JRR-17-34.1

URL: http://www.bioone.org/doi/full/10.3356/JRR-17-34.1

BioOne (www.bioone.org) is a nonprofit, online aggregation of core research in the biological, ecological, and environmental sciences. BioOne provides a sustainable online platform for over 170 journals and books published by nonprofit societies, associations, museums, institutions, and presses.

Your use of this PDF, the BioOne Web site, and all posted and associated content indicates your acceptance of BioOne's Terms of Use, available at www.bioone.org/ page/terms of use.

Usage of BioOne content is strictly limited to personal, educational, and noncommercial use. Commercial inquiries or rights and permissions requests should be directed to the individual publisher as copyright holder. 


\title{
LETTERS
}

J. Raptor Res. 52(1):112-114

(C) 2018 The Raptor Research Foundation, Inc.

\section{Unusual Fishing Behavior of the Eurasian Sparrowhawk (ACCIPITER NISUS)}

\author{
BÉLA MESTER ${ }^{1}$ \\ Hungarian Academy of Sciences, Centre for Ecological Research, Danube Research Institute, Department of Tisza River \\ Research, 4026 Debrecen, Bem tér 18/c, Hungary
}

ThOMas Oliver Mérö

Nature Protection and Study Society-NATURA, Milana Rakića 20, 25000 Sombor, Serbia

KEY WORDS: Eurasian Sparrowhawk; Accipiter nisus; behavior; fishing; predation; urban; winter.

The Eurasian Sparrowhawk (Accipiter nisus; hereafter sparrowhawk) is a generalist predator (Quinn and Cresswell 2004), feeding primarily on birds (over $90 \%$ of prey items in most studies; Newton 1986, Zawadzka and Zawadzki 2001, Bujoczek and Ciach 2009). Sparrowhawks occur frequently in human-altered landscapes, including residential areas, where some individuals overwinter (e.g., McGrady 1991, Mérő and Žuljević 2010). Hunting success can be higher at low temperatures, and lower when precipitation is present and the wind is strong (Hilton et al. 1999, Quinn and Cresswell 2004). Under unfavorable conditions, sparrowhawks can alternatively consume other small prey, such as small mammals (Tomešek and Čermák 2009). We here report on unusual prey selection and hunting behavior of the sparrowhawk.

Our observation took place in Debrecen $\left(462 \mathrm{~km}^{2}\right)$, the third largest city in Hungary, where the sparrowhawk is one of the most common raptors (Bozsko and Juhász 1985). During a walk in the Botanical Garden of the University of Debrecen $\left(47^{\circ} 33.49^{\prime} \mathrm{N}, 21^{\circ} 37.29^{\prime} \mathrm{E}, 126\right.$ masl) on 18 January 2017, we spotted a subadult (2 yr old; SY) sparrowhawk engaged in several short, quick, low flights above the nonfrozen part of a koi (Cyprinus carpio haematopterus) pond (water garden). These apparent predation attempts on koi usually started with hovering flight similar to that of the Eurasian Kestrel (Falco tinnunculus), followed by quick, sharp turns as if in pursuit of a fish, followed by immersion of the sparrowhawk's feet into the water (Fig. 1). Each predation attempt took up to several seconds. Resting time between predation attempts lasted about $3 \mathrm{~min}$ while the sparrowhawk stood on the edge of the ice, intently watching the water. The bird always rested on the opposite side of the previous resting point. While the sparrowhawk was "fish-

\footnotetext{
${ }^{1}$ Email address: mester.bela@okologia.mta.hu
}

ing," we approached from $20 \mathrm{~m}$ to $4 \mathrm{~m}$ so that we could take better photographs. Although the sparrowhawk noticed us immediately, it continued its activity, and made a total of 15 unsuccessful attempts before being disturbed by a man walking near the pond. To our knowledge, no such fishing behavior has previously been reported for the sparrowhawk.

The part of the koi pond where this sparrowhawk attempted to fish was not frozen because of a water circulation system in constant operation, and perhaps because of feeding activity of Mallards (Anas platyrhynchos). Our observation started at $0950 \mathrm{H}$ and lasted until $1045 \mathrm{H}$. The weather was clear and sunny with mild gusts of wind; the temperature was $-1^{\circ} \mathrm{C}$ and the relative humidity was $61 \%$ (both measured at $2 \mathrm{~m}$ above the ground). The average daily temperature had been consistently below $0^{\circ} \mathrm{C}$ since mid-December, and the average depth of snow cover had been approximately $4 \mathrm{~cm}$ since late December.

We suggest three possible explanations for the fishing behavior of this sparrowhawk. First, the most common fish species in the koi pond were goldfish (Carassius auratus auratus) and koi. Swimming slowly near the surface, white, orange, or red koi may appear to be easy prey. Aquarists have reported that avian predators such as herons and kingfishers easily catch koi or goldfish (Stickley 1990). The garish coloration and slow swimming of koi and goldfish near the surface might have attracted the sparrowhawk. A second possible explanation might be the prolonged presence of snow cover that year. Our previous experience observing and trapping sparrowhawks suggests that avian prey may more easily detect a hunting sparrowhawk against a white background (snow cover) than against other background colors. This may reduce hunting success in winter, prompting sparrowhawks to hunt alternative prey. A third explanation may be related to the age of the observed sparrowhawk. Prey such as the slowly swimming, garishly colored koi may trigger innovative hunting attempts among subadult and inexperienced, but motivated individuals. 


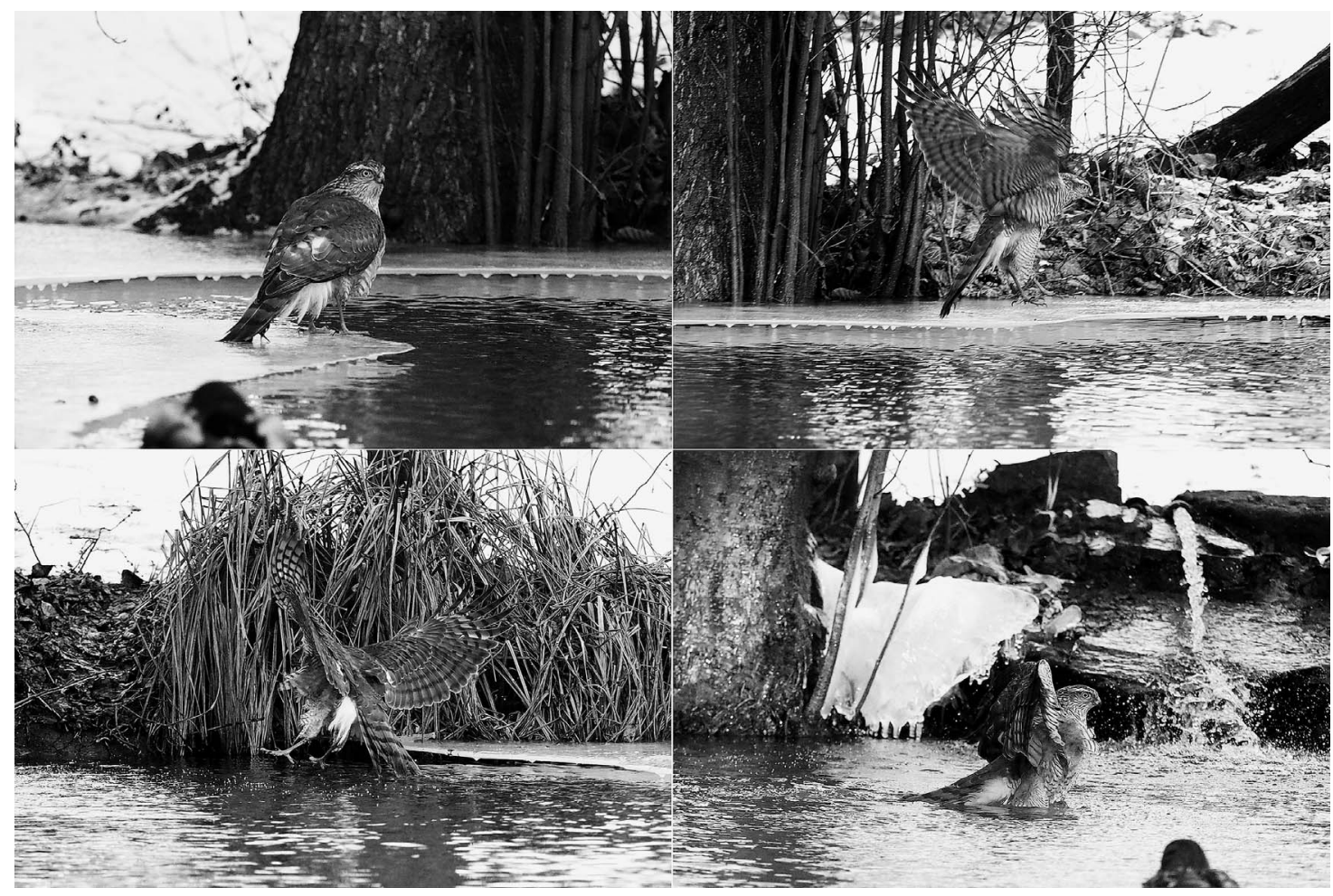

Figure 1. From top left to bottom right: a sparrowhawk resting on ice at the edge of a koi pond, hovering flight over the water, attacking underwater prey, and getting ready to exit the water by flying. (Photos by Béla Mester)

Potential previous, but possibly irreproducible success in catching fish might have encouraged this sparrowhawk to attempt to "fish" again.

These hypotheses are not mutually exclusive, and all three may be related to the unfavorable winter conditions. Generally, in the northern hemisphere the mortality of raptors increases during winter due to starvation or risky hunting in unfavorable conditions (Roth et al. 2005). Mortality of inexperienced subadult birds in particular is highest during their first winter (Lahti et al. 1998). For sparrowhawks, subadult mortality, from fledging through the following April, can be as high as $70 \%$ (Newton et. al 1982, Newton 1986). Risky (e.g., attacking bats in caves; Bereczky 2011) or innovative hunting (this study) may result from food stress due to unfavorable weather conditions or a prey deficit in winter (Newton 1986). In conclusion, our observation suggests that raptors may be able to adopt unusual hunting or foraging behavior and prey selection in response to changing environmental conditions, and changing availability of potential prey resources.

We thank Michael Smart and two anonymous reviewers for help preparing this report. Financial support was provided to $\mathrm{BM}$ by the UNKP-17-3 "New National
Excellence Program of the Ministry of Human Capacities" grant. Photographic equipment was provided by the Olympus Test \& Wow in cooperation with Tenno Foto Kft.

\section{Literature Cited}

BereczKy, A.Sz. 2011. Karvaly (Accipiter nisus) elöfordulása barlangban. Karszt és barlang 1-2:57-58. (In Hungarian.)

BozsKo, Sz. AND L. JuHÁsz. 1985. Debrecen város madárvilága és annak változásai évszázadunkban. A Debreceni Déri Múzeum Évkönyve 64:17-51. (In Hungarian.)

Bujoczek, M. ANd M. Ciach. 2009. Seasonal changes in the avian diet of breeding sparrowhawks Accipiter nisus: how to fulfill the offspring's food demands? Zoological Studies 48:215-222.

Hilton, G.M., G.D. Ruxton, And W. CResswell. 1999. Choice of foraging area with respect to predation risk in redshanks: the effects of weather and predator activity. Oikos 87:295-302.

Lahti, K., M. Orell, S. Rytkönen, and K. Koivula. 1998. Time and food dependence in Willow Tit winter survival. Ecology 79:2904-2916.

MCGRADY, M.J. 1991. The ecology and breeding behaviors of urban sparrowhawks (Accipiter nisus) in Edinburgh, 
Scotland. Ph.D. dissertation, University of Edinburgh, Edinburgh, U.K.

MéRŐ, T.O. AND A. Žuljević. 2010. Birds of Sombor. Nature Protection and Study Society-NATURA, Sombor, Serbia.

Newton, I. 1986. The sparrowhawk. T. and A.D. Poyser. Calton, Staffordshire, U.K.

A.A. Bell, AND I. Wyllie. 1982. Mortality of sparrowhawks and kestrels. British Birds 75:195-204.

Quinn, J.L. AND W. Cresswell. 2004. Predator hunting behavior and prey vulnerability. Journal of Animal Ecology 73:143-154.

Roth, T.C., S.L. LimA, AND W.E. VetTER. 2005. Survival and causes of mortality in wintering Sharp-shinned Hawks and Cooper's Hawks. Wilson Bulletin 117:23-244.
STICKLEY, A.R. 1990. Avian predators on southern aquacultures. Southern Regional Aquaculture Center Publication No. 400, Mississippi Research Station, Mississippi State University, MS U.S.A.

TOMEŠEK, M. AND P. ČERMÁK. 2009. The food spectrum of sparrowhawk (Accipiter nisus L.) and kestrel (Falco tinnunculus L.) in the Chřiby upland, the Czech Republic. Acta Universitatis Agriculturae et Silviculturae Mendelianae Brunensis 17:145-150.

ZAWADZKA, D. AND J. ZAWADZKI. 2001. Breeding populations and diets of the sparrowhawk Accipiter nisus and the hobby Falco subbuteo in the Wigry National Park (NE Poland). Acta Ornithologica 36:25-31.

Received 30 April 2017; accepted 16 August 2017 Associate Editor: James F. Dwyer 